\title{
Impact of Land Use Land Cover Change on Coastal Tourism in Kundapura, Karnataka, Using Multi-temporal Remotely Sensed Data and GIS Techniques
}

\author{
Sheker Naik*, H Gangadhara Bhat $†$ and T N Sreedhara ${ }^{\ddagger}$
}

\begin{abstract}
The present study is an attempt to examine the Land Use Land Cover changes in parts of Kundapura Taluk in Karnataka for the period 2006 and 2016 and its impact on coastal tourism. IRS satellite images of 2006 and 2016 have been used and processed using ERDAS Imagine and ArcGIS. The result indicated tremendous changes, particularly in mixed urban and agricultural land and proved that RS/GIS has advantages over conventional techniques. The result obtained, based on the multi-dated satellite data study, will assist in decision making and help to take appropriate measures to monitor and regulate coastal development in order to achieve sustainable and integrated coastal development.
\end{abstract}

Keywords: Coastal Resources, Tourism, Land Use Land Cover, ERDAS Imagine, ArcGIS.

\section{Introduction}

Coastal tourism can be defined as a "process involving tourists and the people and places they visit, particularly the coastal environment and its natural and cultural resources" (Miller et al.

Mangalore University, Karnataka, India; itsshekar25@gmail.com

† Mangalore University, Karnataka, India; gangadharab@yahoo.com

‡ Mangalore University, Karnataka, India; tnsree@gmail.com 
2002). Coastal zones are usually a tourists' favourite and hence provide a lot of opportunity for tourism development. Most coastal tourism takes place along the shore and in the water immediately adjacent to the shoreline. Coastal tourism today has become a major facet of modern life. Tourism development in the coastal zone can be credited to the rise of Romans and Greeks who established seaside spas, baths and resorts along the Mediterranean and the Adriatic Sea coasts in Europe. Twentieth-century witnessed the rapid growth of coastal tourism around the rest of the world. Modern coastal tourism offers a variety of physical, cultural, and recreational activities that cater to the needs of the demanding coastal tourists. This will result in bringing lots of infrastructure in the coastal areas and will have an adverse impact on the ecosystem.

In the coastal areas, tourism constitutes a significant factor to the transformation of the coast in the environment, economics and social terms (Yeung, 2001). For instance, the transformation experienced by coastal cities like Bali, Pattaya, Phuket, Kuala Lumpur, Manila and many other cities in Asia demonstrate the impact of coastal tourism on environment, society and economy. Coastal tourism harbour beaches and backshore areas provide an amenity for recreation and tourism (Beatly et al. 1994). Coastal landforms, flora and fauna, marine and geological monuments form part of coastal tourism. The coastal environment provides multi-fold resources for water sports and a plethora of coastal habitats, some of which are important components for the viable promotion of alternative tourism.

The literature survey examines a few research works (Brilliant et al. 2013; Yaw et al., 2014; Yuvaraj et al. 2014; Akshitha et al.,2015; Ziaur et al., 2016; Mageswaran et al. 2015; Fikir, 2016; Kaliraj et al. 2017) primarily undertaken to assess the Land Use Land Cover change and its impact on the environment and tourism along the coastal zones. The present LULC change detection study from the point of view of sustainable coastal tourism development is the first of its kind using multi-date satellite images and GIS techniques. Coastal areas are already home to over $50 \%$ of the world population, the additional millions of tourists visiting these areas add to the growing environmental concern. Coastal environments are under increasing pressure, and their problems can no longer be avoided 
or deferred. Against this background, it is important to understand the LULC change and its impact on the coast. Coastal tourism represents the interaction of human systems and environmental systems, whose interactions result in a wide array of human and environmental aspects often resulting in many repercussions (Marafa \& Chau, 2014).

Industrial and tourism development in coastal areas have resulted in the degradation of coastal ecosystems and diminishing coastal and marine biodiversity and productivity in most of the coastal areas of the world. Thus, there is an urgent need to conserve the coastal ecosystems and habitats, including individual plant species, communities, settlements, tourism and recreation, environment, agriculture and so on for the future generations. This can be achieved through integrated sustainable coastal tourism development with the aid of modern technologies like Remote Sensing (RS) and Geographic Information System (GIS).

\section{Study Area}

Study area falling in the Survey of India (SOI) topographical map D43O10 $(48 \mathrm{~K} / 10)$ on $1: 50,000$ scale in Kundapura taluk with an aerial extent of $92.96 \mathrm{~km}^{2}$ (Plate1). Kundapura taluk is surrounded by Udupi in the south, Bhatkal in the north, Sagar and Hosnagara taluks in the east and the Arabian Sea in the west.

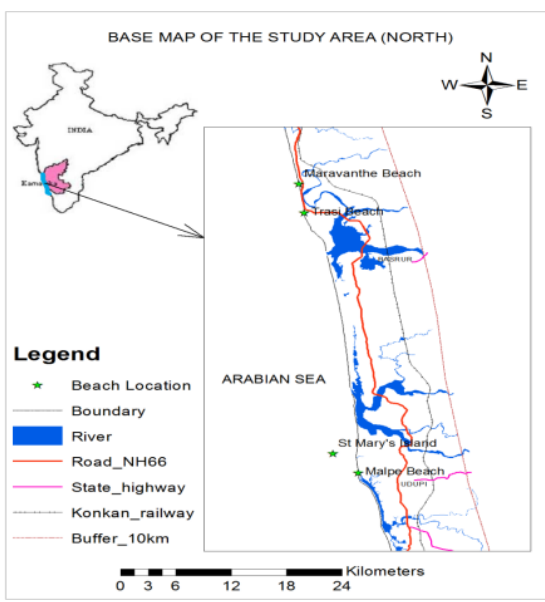

Plate 1: Base map of the study area generated based on SOI topographical map. 
The region has great potential for tourism development with beautiful golden sandy beaches like Trasi, Maravanthe and Gangolli in its village settings. There are other famous tourist places of interest in the surrounding areas.

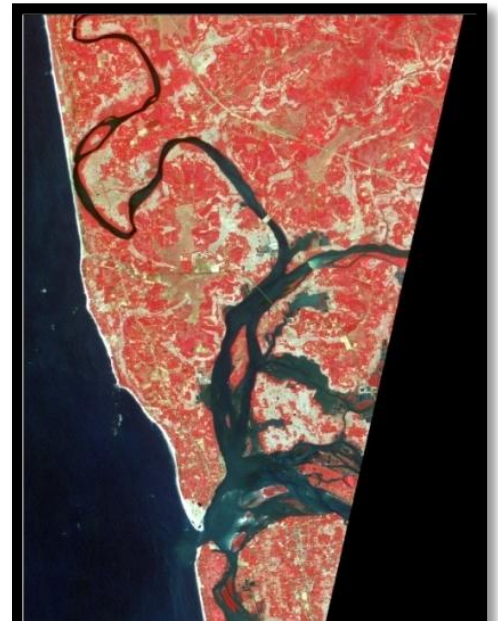

Plate 2: False Color Composite of IRS P6 LISS 4 Image of the Study Area (2006)

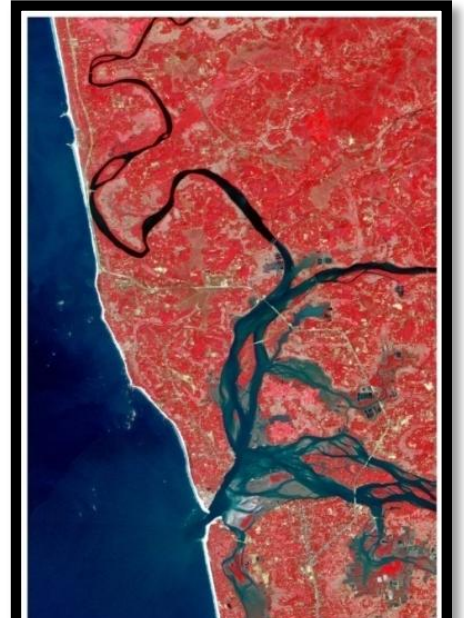

Plate 3: False Color Composite of RS2 LISS 4 Image of the Study Area (2016)

2.1 Population: As per 2011 census the total population of the taluk was 3,68,027. Of which 1,95,281 were female and 1,72,746 were male. The density of the population was 238.09 persons $/ \mathrm{km}^{2}$. About $97.22 \%(3,57,798$ persons) of the population lives in rural areas, and $2.28 \%(10,229$ persons) live in urban areas.

2.2 Climate and Rainfall: The area experiences a typical seaside climate with an average temperature of $26.5^{\circ} \mathrm{C}$. Udupi district gets the highest annual rainfall in Karnataka which is about $4000 \mathrm{~mm}$ annually. In this coastal district, the bulk of the rainfall, i.e. over $85 \%$ occurs during the southwest monsoon season. The temporal variation of rainfall is confined to 3 to 4 months in a year. The rainfall increases from west to east with a coefficient of variability ranging from 18.7 to $18.9 \%$. Average annual rainfall of the district is 4136.3mm (CGWB Report, 2012). 


\section{Materials and Methods}

Survey of India (SOI) Topographical Map D43O10 (48K/10) surveyed during 1967 was used to generate the base map of the study area. Indian Remote Sensing satellite IRS P6 -LISS 4 data of 2006 and Resource Sat 2- LISS 4 data of 2016 were used to generate the Land Use Land Cover maps as well as to carry out the change detection study.

The topographical map was geo-referenced using ArcGIS 10.1 version. Later a Geometrical polynomial model was applied. The selected projection was geographic, and datum was WGS84. Similarly, the satellite imagery was also geo-referenced using the topographic map as the reference map.

The study area was extracted from the topographical map and satellite images using Area of Interest (AOI) option. Layer stacking of the satellite images has been carried out using ERDAS imagine. The band combination of bands 3 (Red), 2 (Green) and 1 (Blue) was found to be more effective in discriminating the LULC classes. Multi-date IRS P6 images were classified based on IUGS (International Union of Geographical Sciences, USA) classification using ERDAS imagine software to understand the Land Use and Land Cover pattern of the study area in a better way.

Land Use and Land Cover map have been generated by digitizing the vector layers, using Arc Map for 2006 and 2016. The area calculation for LULC map has been carried out from the digitized vector layer. The changes occurred in Land Use, Land Cover pattern is obtained by comparing 2006 and 2016 LULC maps. The flow chart showing the steps followed in deriving the statistics of land use pattern of the area is shown in the diagram. 


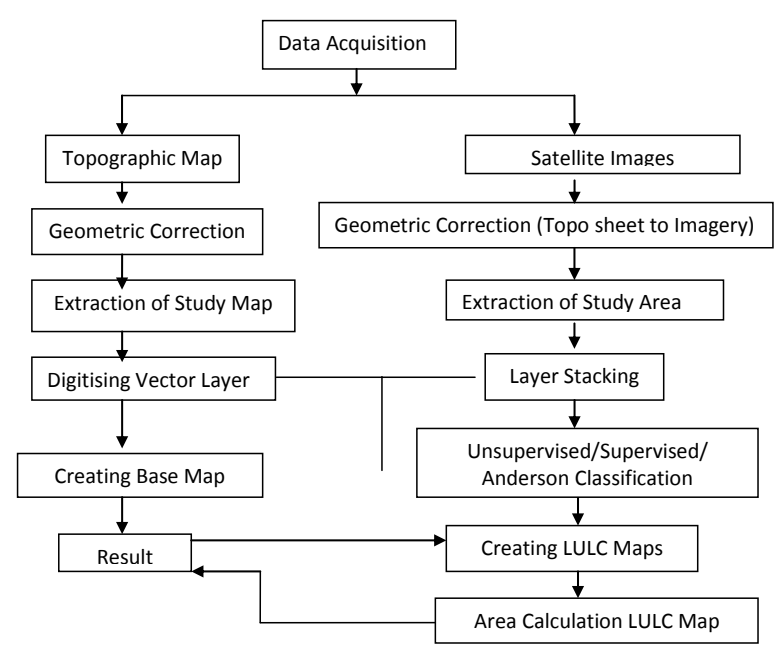

\subsection{Classification Scheme}

The LULC classification system presented in this work includes only the more generalized first and second levels. For LULC data needed for planning and management purposes, the accuracy of interpretation at the generalized first and second level is satisfactory with $87 \%$ of accuracy. The Anderson (1972) level II classification is used to classify the digitized area which is shown below in table 1 .

Table 1: Work Flow Diagram

\begin{tabular}{ll}
\hline \multicolumn{1}{c}{ Level I } & \multicolumn{1}{c}{ Level II } \\
\hline 1 Urban or Built-up & 11 Residential \\
Land & 12 Commercial and Services \\
& 13 Industrial \\
& 14 Transportation, Communication and Utilities \\
& 16 Mixed Urban or Built-up Land \\
& 17 Other Urban or Built-up Land \\
& 21 Cropland Pasture \\
2 Agricultural Land & 24 Other Agricultural Land \\
& 43 Mixed Forest Land \\
4 Forest Land & 51 Streams, Canals \& other water bodies \\
5 Water & 61 Forested Wetland \\
6 Wetland & 62 Non-forested Wetland \\
& 74 Bare Exposed Rocks \\
7 Barren Land & 77 Mixed Barren Land \\
\hline
\end{tabular}




\section{Results and Discussion}

The total area covered in the study is $92.96 \mathrm{~km}^{2}$, which is primarily the coastal area. The important places covered in the study area includes Kundapura (taluk center), Gangolli (minor fishing port), Trasi and Maravanthe (tourist beaches).

4.1 Change in Urban / Built-up land: The study shows significant changes in the urban/built-up land pattern. From the analysis, it is revealed that the urban areas formerly occupied a proportion of $11.43 \mathrm{~km}^{2}$ in 2006 accounting for $12.30 \%$ of TGA (Total Geographical Area) and it has increased to $32.81 \mathrm{~km}^{2}$ by 2016 now covering $35.29 \%$ of TGA (Table 2). The analysis shows an increase of about $21.38 \mathrm{~km}^{2}$ in the mixed urban/built-up land in the past ten years. Most of this development occurred in Kundapura and the surrounding area. Gangolli, a minor port, known for fishing and commercial activities has undergone tremendous change in its land use pattern. The area used for residential, commercial, industrial, transportation and communication purposes also show an increase in their extent.

4.2 Change in Agricultural Land: Agriculture is a dominant activity of the coastal belts of Karnataka. The LULC analysis finds a significant negative change in the agricultural land in the study area. The agricultural area has been further classified into cropland, fallow land, nurseries and ornamental horticultural areas and other agricultural land. The agricultural area cover for the year 2006 was $55.38 \mathrm{~km}^{2}$ (Table 2) covering $59.57 \%$ of TGA and it has declined to $36.92 \mathrm{~km}^{2}$ in 2016 accounting for only $39.71 \%$ of TGA with a sharp decline of about $18.46 \mathrm{~km}^{2}$ of land that has now become built-up land. Conversion of agricultural land into built-up areas has changed the value of land. The migration of rural people into developed cities and lack of skilled personnel available for agricultural practices are the major reasons for the decrease of agricultural land.

4.3 Change in Forest Land: The area accounts for a very small portion of forest land, dominated by mangroves and sparse vegetation along the coast. The study indicates the decline in the forest cover from 2006 to 2016. The forest cover in 2006 was $5.46 \mathrm{~km}^{2}$ accounting for $5.87 \%$ of TGA and it has declined to mere $2.86 \mathrm{~km}^{2}$ in 
$2016\left(3.07 \%\right.$ of TGA). The change in forest cover is about $2.60 \mathrm{~km}^{2}$, which is largely due to the increase in aqua and shrimp-culture activities in the area. Mangroves and Casuarina plantations were cleared for firewood and aquaculture activities.

4.4 Change in Water: The study identified all the water bodies within the study area and digitized on satellite imagery as seen in Plate 8 and Plate 9. The study area is drained by Haladi, Chakra, Kollur rivers and they all join the Arabian Sea near Gangolli forming the Gangolli estuary.

Plate 4 to 9 shows various land use, a land cover map of Kundapura area for March 2006 \& 2016.

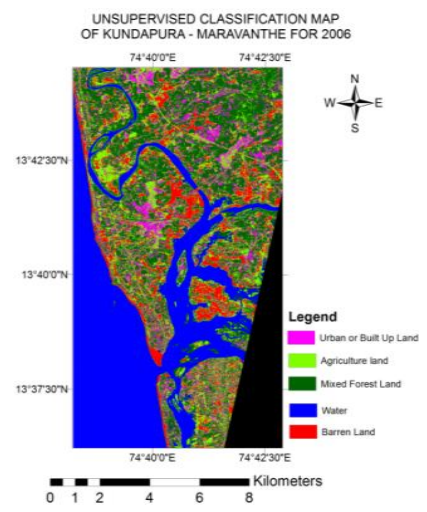

Plate 4: Unsupervised classification map of Kundapur sector - 2006

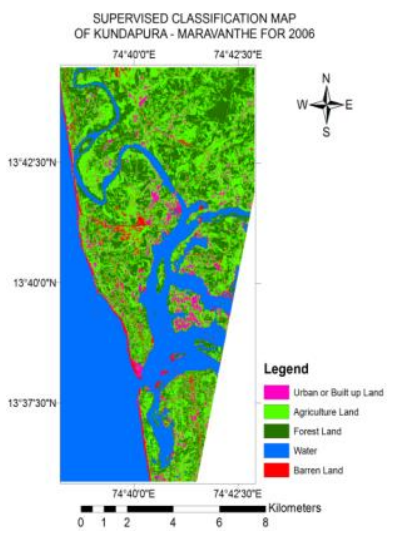

Plate 6: Supervised classification map of Kundapur sector - 2006

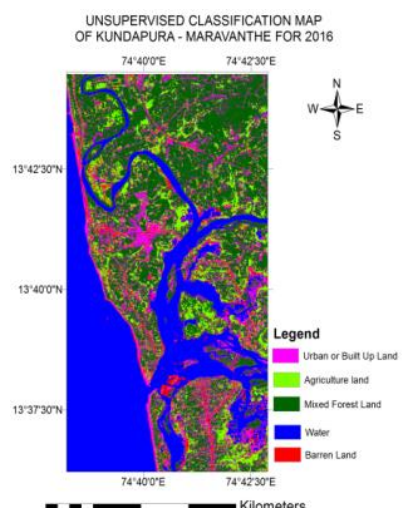

Plate 5: Unsupervised classification map of Kundapur sector - 2016

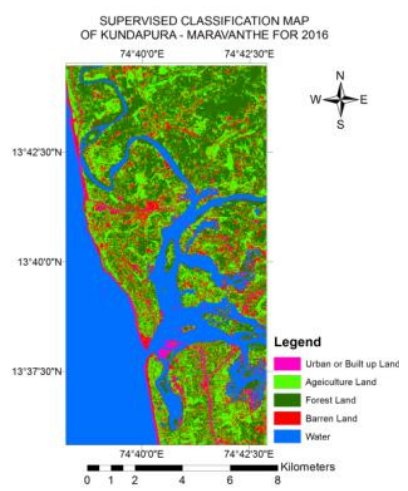

Plate 7: Supervised classification map of Kundapur sector - 2016 


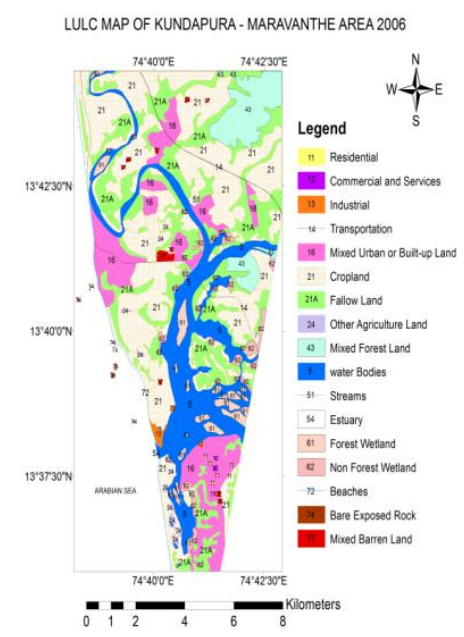

Plate 8: Anderson classification map of Kundapur sector - 2006

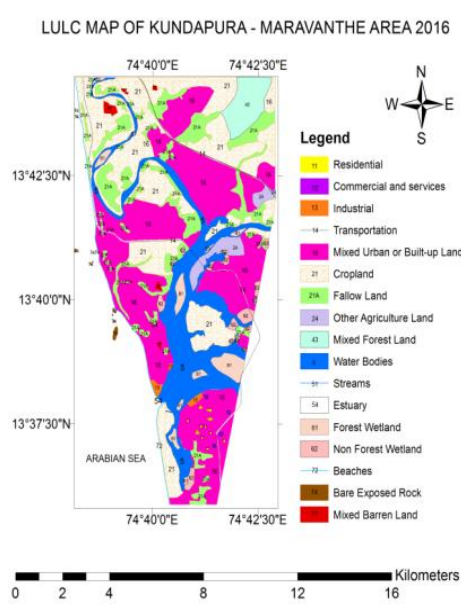

Plate 9: Anderson classification map of Kundapur sector - 2016.

These rivers together form an important source of water in the region. The streams are represented in light blue colour with IUGS code 51 (Plate 8 \& 9). The Gangolli estuaries are represented in dark blue color with IUGS code 54 in the LULC map. The study reports that there is not much change in course and volume of the water.

4.5 Change in Wetland: Wetlands are an important part of the ecology and play a significant role in shaping the environment. The study found that only a very small area of wetland is present in this area and it is in the declining trend. The forested and non-forested wetland that jointly accounted for $3.98 \mathrm{~km}^{2}$ of the area in 2006 has reduced to $3.63 \mathrm{~km}^{2}$ in 2016 . Though it is a minor change $\left(0.35 \mathrm{~km}^{2}\right)$ in the area of the wetland, it should be considered as a major threat to the ecosystem.

4.6 Change in Barren Land: Barren Land is defined as a land that has limited ability to support life and less than one-third of the area has vegetation or other cover. In general, it is an area of thin soil, sand, and rocks. The different categories of barren land covered in the study include the beaches, barely exposed rocks and mixed barren lands.

4.7 Change in Beaches: This region is known for the breathtaking Trasi-Maravanthe beaches that are very popular among the tourists 
and motorists who commute through National Highway 66. The site is a complete delight for the nature lovers.

The Trasi beach is located about $6 \mathrm{~km}$ from Gangolli estuary. The general condition of the beach is much to be desired pertaining to its quality. It is noticed from the study that recent developmental activities like the expansion of $\mathrm{NH} \mathrm{66,} \mathrm{wetland} \mathrm{filling} \mathrm{and}$ encroachment of natural areas for commercial purposes are causing environmental problems along the beach and its vicinity.

Table 2: Statistical Distribution of LULC class categories in the study area for 2006 and 2016

\begin{tabular}{|c|c|c|c|c|c|c|}
\hline \multicolumn{7}{|c|}{ LU/LC Kundapura - Maravanthe Area for the Year 2006 \& 2016} \\
\hline Level 1 & Level 2 & $\begin{array}{l}\text { Area } \\
\text { in } \mathrm{km}^{2} \\
2006\end{array}$ & $\begin{array}{l}\text { \% of } \\
\text { TGA }\end{array}$ & $\begin{array}{l}\text { Area in } \\
\mathrm{Km}^{2} \\
2016\end{array}$ & $\begin{array}{l}\text { \% of } \\
\text { TGA }\end{array}$ & $\begin{array}{c}\text { Change in } \\
\text { Area } \\
\mathrm{Km}^{2}\end{array}$ \\
\hline & 11 Residential & 0.04 & 0.04 & 0.13 & 0.14 & 0.09 \\
\hline 1 Urban / & 12 Commercial & & & & & \\
\hline Built-up & \& Services & 0.03 & 0.04 & 0.15 & 0.16 & 0.12 \\
\hline Land & $\begin{array}{l}13 \text { Industrial } \\
16 \text { Mixed Urban } \\
\text { or }\end{array}$ & 0.31 & 0.33 & 0.36 & 0.39 & 0.05 \\
\hline & Built-up Land & 11.05 & 11.89 & 32.17 & 34.61 & 21.12 \\
\hline 2 Agri- & 21 Cropland & 35.20 & 37.86 & 24.35 & 26.19 & -10.85 \\
\hline cultural & 21a Fallow Land & 19.85 & 21.36 & 10.88 & 11.71 & -8.97 \\
\hline Land & $\begin{array}{l}24 \text { Other } \\
\text { Agricultural }\end{array}$ & & & & & \\
\hline & Land & 0.33 & 0.35 & 1.69 & 1.82 & 1.36 \\
\hline $\begin{array}{l}4 \text { Forest } \\
\text { Land }\end{array}$ & $\begin{array}{l}43 \text { Mixed Forest } \\
\text { Land }\end{array}$ & 5.46 & 5.87 & 2.86 & 3.08 & -2.60 \\
\hline 5 Water & $\begin{array}{l}51 \text { Water Bodies } \\
61 \text { Forested }\end{array}$ & 16.15 & 17.37 & 16.24 & 17.47 & 0.09 \\
\hline $\begin{array}{l}6 \text { Wet } \\
\text { land }\end{array}$ & $\begin{array}{l}\text { Wetland } \\
\text { 62Non- Forested }\end{array}$ & 2.11 & 2.27 & 2.23 & 2.40 & 0.12 \\
\hline & $\begin{array}{l}\text { Wetland } \\
74 \text { Bare Exposed }\end{array}$ & 1.87 & 2.01 & 1.40 & 1.50 & -0.47 \\
\hline $\begin{array}{l}7 \text { Barren } \\
\text { Land }\end{array}$ & $\begin{array}{l}\text { Rock } \\
77 \text { Mixed Barren }\end{array}$ & 0.16 & 0.17 & 0.14 & 0.15 & 0.02 \\
\hline & Land & 0.40 & 0.43 & 0.37 & 0.39 & -0.03 \\
\hline & Total & 92.96 & 100 & 92.96 & 100 & \\
\hline
\end{tabular}

Maravanthe Beach is located $15 \mathrm{~km}$ north of Kundapur town. The beach shows a steep gradient from the high water level with no consistent strand flora in the backshore. Coastal erosion has played severe havoc, eroding a large portion of the backshore. The beach is under severe coastal erosion and human encroachment. It was understood from the survey and previous studies that Government of Karnataka has spent a huge amount 
of money on seawall construction. The prospects of controlling the same are bleak as it is very close to the National Highway No. 66. The backshore is barren at some places. Proper attention and care are badly needed for the upkeep of the beach. Under protective measures the beach can be developed as a popular recreational spot.

\section{LU/LC Distribution in the Study Area During 2006 - 2016}

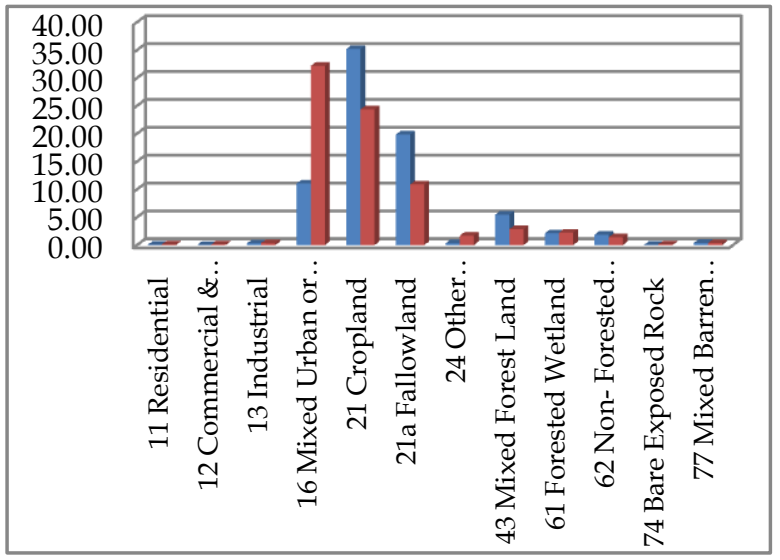

Area in Km2 2006

- Area in Km2 2016

Chart 1: LULC distribution in the study area 2006-2016

Currently, the construction of breakwater work is under progress in Maravanthe, taken up by the Karnataka Fisheries Department. This project is expected to provide the much-needed anchoring space and fish landing point for the fishing trawlers, owned by fishermen of Maravanthe community.

The south of the southern breakwater, the beach is wide, and coastal vegetation is seen (sand binders). Sand binders and coconut vegetation are seen in the hinterlands too. Field survey and recent Google images show erosion of beach in the area lying immediately north of the northern breakwater, whereas, in the area lying immediately south of the southern backwater, beach accretion can be seen.

The other development noticed in the area includes the expansion of $\mathrm{NH} 66$ which is also expected to create additional pressure on the surrounding areas. 
4.7.1 Recreational Value of Trasi and Maravanthe beaches: It is one of the must-visit tourist spots of Karnataka. The National Highway ( $\mathrm{NH} \mathrm{66)}$ passes close to this beach, and a stretch of one $\mathrm{km}$ of this road is bordered by the shores of the Arabian Sea on one side and Sauparnika river on the other. The endless stretch of golden sand, palm trees, blue sky and the flow of the sea, attract a large number of tourists to Maravanthe. Under protection measures, the beach can be salvaged for development.

4.8 Bare Exposed Rock: The bare exposed rock category included in this study is the rock exposure on the sea along the coast. The study finds few patches of rock exposure near the northern breakwaters of Maravanthe and north of Gangolli estuary.

4.9 Mixed Barren Land: The mixed barren land category is used when a mixture of barren land features occur, and the dominant land use occupies less than two-thirds of the area. The study identifies a small decline of mixed barren land during the study period.

\section{Major findings of the study}

The study found a high density of population settlement in the coastal areas causing over-exploitation of coastal resources and thereby harming the coastal ecology. The density of population in the study area is 329 people per square kilometre.

It is noticed from the study that land use pattern has influenced the hydrological regime through high surface runoff during monsoon season and decline in groundwater level during the non-monsoon season.

It is observed that the study area generally faces severe erosion during the SW monsoon and accretion during post-monsoon period. However, some parts of the coastline in the study area show continuous and significant erosion.

Kundapura, Kodi, Gangolli and Maravanthe are highly eroding beaches. These beaches, in spite of their beautiful landscape, are highly vulnerable to any type of developments.

In some areas like Trasi and Maravanthe, beach width has been reduced considerably due to a reduction in sediment supply from 
human activities such as the construction of breakwaters, jetties, seawalls and damming of rivers.

Coastal shoreline study indicated migration of river mouth in the Gangolli estuary.

River islets near Kundapura with beautiful landscape have great potential for developing it as health tourism destinations.

The study reveals the expansion of urban areas in the interiors and outskirts of Kundapura town. It is observed from the study that the most significant changes are made in the mixed urban lands as a major portion of agricultural and croplands are converted into mixed urban or built-up land.

It is found from the study that the urban/built-up land increased by $21.38 \mathrm{~km}^{2}$ in 2016 compared to the urban land use of 2006 .

A sharp decline of $18.46 \mathrm{~km}^{2}$ of agriculture land is observed for Kundapura sector during 2016. The study also revealed a decline of forest cover in the study area.

Chakra-Haladi-Kollur rivers are the important sources of water in the study area. These river systems play a significant role in the coastal geomorphologic processes, which are responsible for the formation of different kind of landforms at the lower reaches.

Accelerated urban growth in the study region resulted in excessive building, over-exploitation of groundwater, pollution of soil and groundwater reserves and resource extraction.

The decline of tropical mangroves and coastal wetlands have been observed in Kundapur sector. Various anthropogenic activities like shrimp farming, aquaculture ponds, construction of breakwaters (Maravanthe), jetties, road, and commercial activities along the coast have deteriorated the health of the mangroves.

Violation of the Coastal Regulation Zone is observed in the study area. These violations have already created additional pressure on coastal flora and fauna. 


\section{Recommendations from the Study}

The integrated coastal tourism development plan should be formulated with remote sensing and GIS techniques to develop sustainable coastal tourism in the selected coastal areas of Karnataka.

The beautiful river islets, particularly in the Kundapura sector, should be developed as health resorts as they have a very conducive atmosphere for rest, relaxation and recreational activities with minimum or no harm to the planet.

The beaches in the study area should be provided with the supportive amenities for undertaking various types of aquatic and recreational activities.

Beach nourishment programmes can be undertaken aggressively in selected areas to solve the problems of coastal erosion. However, the feasibility of the same should be analysed.

The construction of seawalls and breakwaters should be restricted to areas where they are extremely necessary, and in all other areas, beaches should be protected with bio-shielding.

Measures should be taken to promote beaches as zero waste areas through awareness programme among the tourists and the villagers. Providing sanitation facilities and periodic beach cleaning activities should be undertaken.

Beaches should be evaluated for their richness of flora and fauna, and an action plan should be created for appropriate restoration and conservation of beach flora and fauna for suitable beaches. Nurseries may be started with the cooperation of the horticultural department and the local people to promote and conserve coastal plant species.

In some of the beaches (Trasi and Maravanthe) marine turtles like Olive Ridley visit to lay eggs. These turtles should be given special priority and adequate protection.

It is also suggested that the government ensure that the citizens strictly follow the coastal setback limits. The demarcation of the area will help to protect the coastal resources and prevent any 
anthropogenic activities and damage to coastal resources by adhering to the guidelines of the CRZ Act.

It should be made mandatory that the builders and real estate promoters compulsorily make provision for rainwater harvesting in their buildings and apartments. Any builder who fails to meet such provisions should stand to lose their license.

Measures should be taken to encourage the development of the agriculture sector in the region. It has been observed that there is a significant decline of agriculture land in the study area. The government should take steps to expand agricultural activities by offering incentives to the farmers.

Beach Management Authority should be established to ensure the carrying capacity of the beach, LULC analysis and suitability, community empowerment and other requirements of beach visitors. The beach management authority should be made responsible for strengthening the local economy.

Measures should be taken to restore and protect the coastal wetlands. Wetlands are an important source of renewable food production and potable water availability for humans and livestock (Reddy et al. 2017). Wetlands are also important for the coexistence of diverse populations of coastal plant and species. Efforts should be made to integrate wetlands of varied nature in the conservation network so as to protect and preserve the wetlands of coastal Karnataka.

\section{Conclusion}

Remote sensing and GIS Technology is regarded as an effective tool for carrying out spatial analysis. Multi-dated remotely sensed satellite images provide up to date information and help to detect and monitor the significant changes. LULC change study is very important for ensuring sustainability and planned development from the beach tourism point of view. The present study demonstrates the usefulness of multi-dated satellite images in preparation of existing LULC maps of Kundapura and Maravanthe area. The analysis of the study indicates rapid expansion in the mixed urban land cover and the decline of agriculture and 
vegetation between the years 2006 and 2016. Therefore, it is concluded that with increasing pressure on land, the intensive urbanisation has extended even to the expense of ecologically sensitive areas such as beaches, mangroves and marshy lands.

\section{References}

Akshitha, H., Bhat, G., \& Naveenchandra, B. (2015). Land Use Land Cover Change Detection Study in parts of Mangalore Taluk, Karnataka using multi-temporal remotely sensed data and GIS Techniques. Proceedings of GITA-2K15 held at SMVITM, Bantakal, Udupi.

Anderson, J. R., Hardy, E. E., \& Roach, J. T. (1972). A Land Use Classification System for Use with Remote-Sensor Data. U.S. Geol. Survey Cire. 671, 16.

Beatley, T., \& Brower, D. J. (1994). An Introduction to Coastal Zone Management. Washington, DC. Island Press, 186.

Brilliant, R., Varghese, V. M., \& Pradeepkumar, A. P. (2013). Landuse/Land Cover Evaluation for Sustainable Coastal Tourism Development of Varkala, Kerala. International Journal of Plant, Animal and Environmental Sciences, 3(1).

CGWB Report. (2012). Central Ground Water Board - Udupi District Karnataka, Govt. of India, Ministry of Water Resources, Ground Water Information Booklet.

Fikir, A. (2016). Land Use and Land Cover Change in the Coastal Area of Watamu Mida Creek, Kenya. Open Journal of Forestry, 6, 230-242.

Retrieved February 10, 2017, from http:// www.scirp.org/ journal/ojfhttp://dx.doi.org/ 10.4236/ ojf.2016.64019

Kaliraj, S. N., Chandrasekar, K. K., Ramachandran, Srinivas, Y., \& Saravanan, S. (2017). Coastal land use and land cover change and transformations of Kanyakumari coast, India using remote sensing and GIS. The Egypthian Journal of Remote Sensing and Space Science, in Press.

Lawal, M., \& Marafa, K. C. (2014). Framework for Sustainable Tourism Development on Coastal and Marine Zone Environment. Journal of Tourism, Leisure and Global Change, 1.

Mageswaran, T., Sachitanadanam, V., Sridhar, R., Thirunavukarasu, \& Ramesh. (2015). Mapping and Monitoring of Land Use / Land Cover Changes in Neil Island (South Andaman) Using Geospatial Approaches. Indian Journal of Geo-marine sciences, 44 (11). 
Mareddy, A. R., Shah, A., \& Davergave, N. (2017). Environmental Impact Assessment: Theory and Practice. Elsevier Science. Retrieved June 25, 2017, from https:// books.google.co.in/books?id=cBtYDgAAQBAJ.

Miller, M. L., Auyong, J., \& Naina, P. H. (2002). Sustainable Coastal Tourism: Challenges for Management, Planning and Education.Retrieved March 10, 2017, from http://nsgl.gso.uri.edu/washu/washuw99003/1Introduction_ Miller.pdf

Yaw, A. B., Alex, B. A., Kwasi, A. A., Kwabena, E. A., \& John, B. D. (2014). Assessing Land Cover Changes from Coastal Tourism Development in Ghana: Evidence from the Kokrobite-Bortianor Coastline, Accra. Civil and Environmental Research, 6 (6).

Yeung, Y. M. (2001). Coastal Mega Cities in Asia: Transformation, Sustainability and Management. Ocean E Coastal Management, 44, 319333.

Yuvaraj, E., Saravanan, \& Dharanirajan, K. (2014) Assessment of Land Use and Land Cover Changes in South Andaman Island Using Remote Sensing and GIS. International Journal of Geomatics and Geosciences, 5(1).

Ziaur, R., Khanum, F., \& Kazmi, S. J. H. (2016). Evaluation of Land Cover Changes at the Coast of Sindh through Successive Landsat Imageries. Journal of Earth Science and Climate Change (ISSN: 2157-7617), 7(1). 